\title{
Implementasi Akuntansi Zakat Infaq dan Shadaqah Berdasarkan PSAK 109
}

\section{Implementation of Accounting Zakat, Infaq and Shadaqah Based on PSAK 109}

\author{
Rozy Widhi Bayu Pratama dan Ahmad Roziq ${ }^{1}$ \\ Jurusan Akuntansi, Fakultas Ekonomi dan Bisnis, Universitas Jember (UNEJ) \\ Jln. Kalimantan 37, Jember 68121 \\ E-mail: ahmadroziq@yahoo.com
}

\begin{abstract}
Abstrak
Penelitian ini bertujuan untuk mengetahui implementasi akuntansi zakat, infaq dan shadaqah berdasarkan PSAK 109 yang berfokus pada penyajian laporan keuangan pada lembaga pengelola zakat di Kabupaten Jember. Penelitian ini merupakan penelitian kualitatif analisis wacana kritis, yaitu metode yang dilakukan dengan cara mengumpulkan, mempersiapkan, serta menganalisis data berupa laporan keuangan organisasi sehingga nantinya dapat memberikan gambaran yang jelas tentang penerapan akuntansi zakat, infaq dan shadaqah berdasarkan PSAK 109 pada lembaga-lembaga pengelola zakat di Kabupaten Jember. Metode pengolahan data menggunakan wawancara beserta dokumen yang terkait dan disertai dengan salah satu keabsahan data yaitu triangulasi. Hasil penelitian menunjukkan terdapat banyak perbedaan dalam proses akuntansi serta penyajian laporan keuangan yang dilakukan oleh Lembaga Pengelola Zakat di Kabupaten Jember. Dari lima lembaga pengelola zakat yang diteliti masih hanya satu lembaga yang telah menerapkan PSAK 109.
\end{abstract}

Kata Kunci: Akuntansi, Zakat, Infaq, Shadaqah, PSAK 109.

\section{Abstract}

This research aims to know the accounting implementation of zakat, infaq and shadaqah based on PSAK NO. 109 which focuses on the presentation of the financial report on the institution of Zakat in Jember. This research is qualitative research of critical discourse analysis, a method that is done by collecting, preparing, and analyzing the data in the form of the financial statements of the Organization so that it can eventually give a clear picture of the implementation of the accounting of religious obligatory, infaq and charity based on PSAK NO. 109 on the institutions of zakat in Jember. Method of processing data using interviews, along with related documents and accompanied by one of the validity of the data i.e. triangulation. The results showed that there are many differences in the accounting process as well as the presentation of the financial statements conducted by institutions of zakat in Jember. Of the five institutions researched zakat Manager is still only one agency who has applied PSAK NO. 109.

Keywords: Accounting, Zakat, Infaq, Shadaqah, PSAK 109.

\section{Pendahuluan}

Perkembangan ekonomi syariah di Indonesia dalam beberapa tahun terakhir mengalami perkembangan yang cukup pesat serta tercatat paling stabil baik dalam industri perbankan maupun keuangan syariah. Salah satu instrumen dalam perekonomian syariah yaitu zakat. Zakat merupakan instrumen yang digunakan dalam menyeimbangkan perekonomian suatu Negara. Dalam Islam dikenal beberapa bentuk insentif bagi perekonomian yang sangat unik bagi masyarakat miskin yaitu zakat, infak dan shadaqah. Zakat bersifat wajib, sedangkan infak dan shadaqah bersifat sukarela. Menurut pernyataan standar akuntansi keuangan PSAK No. 109, Zakat adalah harta yang wajib dikeluarkan oleh muzakki sesuai dengan ketentuan syariah untuk diberikan kepada yang berhak menerimanya (mustahiq). Sedangkan Infaq dan Shadaqah menurut PSAK No.109 yakni Infak/sedekah adalah harta yang diberikan secara sukarela oleh pemiliknya, baik yang peruntukannya dibatasi (ditentukan) maupun tidak dibatasi.

Dalam perkembangannya, saat ini secara signifikan lembaga pengelola zakat mengalami kemajuan pesat. Di Indonesia, pengelola dana zakat, infak, shadaqah (ZIS) diatur dalam 1 Corresponding Author
Undang-Undang No 38 tahun 1999 tentang Pengelolaan Zakat. Namun saat ini telah tersedia Undang-Undang yang baru yaitu Undang-Undang No. 23 Tahun 2011 tentang Pengelolaan Zakat. Undang-Undang yang baru ini mengatur tentang Organisasi Pengelola Zakat (OPZ) yang boleh beroperasi di Indonesia. OPZ yang disebutkan dalam UU tersebut adalah Badan Amil Zakat (BAZ) dan Lembaga Amil Zakat (LAZ). Menurut Fathonah (2013), organisasi pengelola zakat yang mempunyai tugas mengelola zakat memerlukan laporan keuangan untuk mempermudah kinerjanya. Laporan keuangan digunakan sebagai bentuk transparasi dalam pengelolaannya dan juga sebagai bentuk pertanggungjawaban kepada donatur atau pengguna laporan keuangan lainnya. Maka dari itu, dibutuhkan laporan keuangan sebagai media antara pengelola dan masyarakat. Untuk dapat menghasilkan laporan keuangan yang berkualitas, organisasi pengelola zakat disyaratkan memiliki sistem akuntansi yang baik.

Sistem akuntansi yang baik dan transparan yang sesuai dengan PSAK No 109 tentang Akuntansi Zakat dan Infak/Sedekah, merupakan salah satu faktor yang akan meningkatkan kepercayaan masyarakat terhadap organisasi pengelola zakat dan upaya untuk memantapkan pengelolaan

e-Journal Ekonomi Bisnis dan Akuntansi, 2017, Volume IV (1) : 35-39 
lembaga-lembaga amil zakat sebagai suatu sistem pemberdayaan ekonomi umat Islam. Sistem pendistribusian yang tepat guna dan efektif serta profesional akan mampu membantu masyarakat terlepas dari kemiskinan. Selain itu, laporan keuangan yang dihasilkan lembaga pengelola zakat merupakan bentuk akuntabilitas. Hal ini telah diatur dalam PSAK No. 109 mengenai pengakuan, pengukuran, penyajian dan pengungkapan transaksi zakat, infak/shadaqah

Dari penjelasan di atas, peneliti berinisiatif untuk melakukan studi implementasi akuntansi zakat, infak, dan shadaqah menurut PSAK No. 109 dengan akuntasi zakat, infak, dan shadaqah yang diimplementasikan pada lembaga pengelola zakat. Fokus dari peneliti yakni bentuk penyajian laporan keuangan yang dianalisis untuk mengetahui tingkat kesesuaian dengan PSAK No. 109. Lembaga pengelola zakat yang akan dianalisis adalah lembaga pengelola zakat yang ada di Kabupaten. Karena hingga saat ini belum terdapat BAZDA di Kabupaten Jember, sehingga peran lembaga zakat sangat besar dalam proses pengelolaan zakat, infaq dan shadaqah di Kabupaten Jember. Lembaga-lembaga tersebut yaitu RIZKI (Rumah Itqon Zakat Infak), BMH Cabang Jember (Baitul Mal Hidayatullah), LAZISMU (Lembaga Amil, Zakat, Infak dan Shodaqoh Muhammadiyah), UPZ DEPAG (Unit Pengelola Zakat Departemen Agama Jember), AZKA (Amil Zakat AlBaitul Amien), YDSF Cabang Jember (Yayasan Dana Sosial Alfalah), Yatim Mandiri Cabang Jember.

\section{Metode}

Penelitian ini merupakan penelitian kualitatif dengan pendekatan analisis wacana kritis. Analisis wacana kritis memandang bahasa sebagai faktor yang penting, bahasa tersebut digunakan dalam melihat ketimpangan kekuasaan yang terjadi di masyarakat. Karakteristik penting dari wacana kritis sendiri dipaparkan oleh Teun A. Van Djik, Fairclough, dan Wodak (dalam Eriyanto. 2009: 8-13) merupakan tindakan, konteks, historis, kekuasaan, dan ideologi.

Berdasarkan pendekatan ini peneliti akan mengumpulkan, mempersiapkan, serta menganalisis data berupa laporan keuangan organisasi sehingga nantinya dapat memberikan gambaran yang jelas tentang penerapan akuntansi zakat, infaq dan shadaqah berdasarkan PSAK 109 pada lembaga-lembaga pengelola zakat di Kabupaten Jember.

Untuk memperoleh data lapangan yang diperlukan, penelitian dilakukan di 7 Lembaga Pengelola Zakat yang ada di Kabupaten Jember, Jawa Timur. Lembaga-lembaga tersebut yaitu RIZKI (Rumah Itqon Zakat Infak), BMH Cabang Jember (Baitul Mal Hidayatullah), LAZISMU (Lembaga Amil, Zakat, Infak dan Shodaqoh Muhammadiyah), UPZ DEPAG (Unit Pengelola Zakat Departemen Agama Jember), AZKA (Amil Zakat Al-Baitul Amien), YDSF Cabang Jember (Yayasan Dana Sosial Alfalah), Yatim Mandiri Cabang Jember. Namun, karena tidak turunnya ijin penelitian pada lembaga AZKA (Amil Zakat Al-Baitul Amien) dan Yatim Mandiri Cabang Jember akhirnya penelitian ini dilakukan di 5 Lembaga Pengelola Zakat di Kabupaten Jember, Jawa Timur yakni RIZKI (Rumah Itqon Zakat Infak), BMH Cabang Jember (Baitul Mal Hidayatullah), LAZISMU (Lembaga Amil, Zakat, Infak dan Shodaqoh Muhammadiyah), UPZ DEPAG (Unit Pengumpul Zakat Departemen Agama Jember), serta YDSF Cabang Jember (Yayasan Dana Sosial Alfalah).

\section{Uji Keabsahan Data}

Validitas dalam penelitian kualitatif adalah kepercayaan dari data yang diperoleh dan analisis yang dilakukan peneliti secara akurat mempresentasikan dunia sosial di lapangan. Uji keabsahan data pada penelitian kualitatif meliputi credibility (validitas internal) dengan cara triangulasi, transferability (validitas eksternal), dependability (reliabilitas) dan conformability (objektifitas) (Sugiyono, 2014). Pada penelitian ini, akan digunakan cara triangulasi dalam pengujian data. Menurut Moleong (2004) triangulasi adalah teknik pemeriksaan keabsahan data yang memanfaatkan sesuatu yang lain dalam membandingkan hasil wawancara terhadap objek penelitian. Dalam penelitian ini digunakan triangulasi teknik guna menguji keabsahan datanya. Ini berarti bahwa pengecekan keabsahan atau validitas data dilakukan dengan menggunakan teknik pengumpulan data yang berbeda-beda untuk mendapatkan data dari sumber yang sama. Peneliti menggunakan observasi partisipatif, wawancara mendalam, dan dokumentasi untuk sumber data yang sama secara serempak.

\section{Metode Analisis Data}

Analisis data adalah proses mencari dan menyusun secara sistematis data yang diperoleh dari hasil wawancara, catatan lapangan, dan dokumentasi, dengan cara mengorganisasikan data ke dalam kategori, menjabarkan ke dalam unit-unit, melakukan sintesa, menyusun ke dalam pola, memilih yang penting dan yang akan dipelajari, dan membuat kesimpulan sehingga mudah dipahami oleh diri sendiri maupun orang lain (Sugiyono, 2014:89). Teknik analisis data yang digunakan dalam penelitian ini adalah analisis data pendekatan kualitatif kritis. Hasil penelitian serta analisisnya diuraikan dalam suatu tulisan ilmiah yang berbentuk narasi, kemudian dari analisis yang telah dilakukan diambil suatu kesimpulan. Dalam kaitan dengan ini maka dapat digunakan model analisis interaktif dari Miles \& Huberman (1992). Mereka mengungkapkan bahwa aktivitas dalalam analisis data kualitatif dilakukan dengan cara interaktif dan berlangsung secara terus menerus sampai tuntas, sehingga datanya sudah jenuh. Dalam model analisis data terdiri atas tiga komponen, yaitu Reduksi Data (Data Reduction), Penyajian Data (Display Data), dan Penarikan Kesimpulan dan Verifikasi (Conclusion Drawing).

\section{Hasil dan Pembahasan}

Kelima lembaga amil zakat yang digunakan sebagai responden yaitu Unit Pengumpul Zakat (UPZ) Kantor Departemen Agama Kabupaten Jember, Lembaga Amil Zakat Muhammadiyah (LAZISMU) Jember, Yayasan Dana Sosial Al Falah (YDSF) Jember, Baitul Maal Hidayatullah (BMH) Jember, Rumah Itqon Zakat Infak (RIZKI) telah membagi aktivitasnya sesuai dengan divisi yang dikelolanya sehingga kegiatan lembaga yang dijalankan lebih efektif dan efisien. Namun pada Unit Pengumpul Zakat (UPZ) Kantor Departemen Agama Kabupaten Jember serta Baitul Maal Hidayatullah (BMH) Cabang Jember dalam struktur organisasinya masih kurang efektif karena masih terdapat penggandaan fungsi dan tugas karena adanya seksi yang tidak menjalankan tugasnya dan kurangnya tenaga kerja yang terdapat pada lembaga sehingga harus digantikan atau dijalankan oleh ketua dan sekretaris. Seksi tersebut antaralain seksi pengumpulan, pendistribusian pendayagunaan, dan pengembangan. 
Sebaiknya keempat seksi tersebut bisa menjalankan tugasnya masing-masing agar kinerja menjadi lebih efektif dan efisien agar dapat mengelola zakat dengan lebih baik lagi. Sedangkan untuk keempat lembaga amil zakat yang lain dalam struktur organisasinya telah berjalan dengan baik dan tidak ada penggandaan tugas. Semua sudah berjalan sesuai dengan tugas dan wewenang masing-masing. Proses pengumpulan, pendistribusian dan pendayagunaan dana yang dilakukan oleh kelima lembaga amil zakat ini telah sesuai dengan Undangundang No. 23 Tahun 2011. Dari segi pengumpulan dana yang dilakukan oleh kelima lembaga amil zakat ini terdapat perbedaan, dimana Unit Pengumpul Zakat (UPZ) Kantor Departemen Agama Kabupaten Jember mengumpulkan dana zakat, infaq dan shadaqah hanya berasal dari lingkungan internal yaitu para pegawai di Kantor Departemen Agama Kabupaten Jember dan 18 Satker dibawah naungannya.

Pendistribusian dana zakat, infaq dan shadaqah lebih didayagunakan dibidang pendidikan yang bersifat tetap serta dibidang sosial yang bersifat insidentil kepada kedelapan asnaf. Sedangkan untuk keempat lembaga amil zakat yang lainnya yakni LAZISMU Jember, YDSF Jember, BMH Cabang Jember, serta RIZKI pengumpulan dana zakat berasal dari para donatur yaitu masyarakat umum dan sudah lebih luas dalam pendistribusian dan pendayagunaan dana zakat kepada 8 asnaf. Dalam pendistribusian atau pendayagunaannya terbagi atas pendayagunaan dalam bidang ekonomi, bidang kesehatan, bidang pendidikan, bidang kemanusiaan serta pendayagunaan untuk dana yatim, qurban, serta dana wakaf yang disalurkan untuk kedelapan asnaf yang berhak menerima.

\section{Proses Akuntansi Lembaga Amil}

Sesuai dengan tugas pokok lembaga amil zakat yaitu mengumpulkan, mendistribusikan, dan mendayagunakan sesuai dengan ketentuan agama, maka peranan akuntansi sangat berkaitan dengan proses pengumpulan, pendistribusian, dan pendayagunaan serta pembuatan laporan keuangan oleh lembaga amil zakat itu sendiri dengan tujuan untuk mempertanggungjawabkan kinerjanya kepada masyarakat umum, khususnya kepada para muzakki yang telah mempercayakan dana ziswafnya kepada lembaga zakat. Proses pencatatan siklus akuntansi Unit Pengumpul Zakat (UPZ) Kantor Departemen Agama Kabupaten Jember dimulai dari adanya penerimaan atau pengeluaran yang dibuktikan dengan bukti transaksi yaitu kwitansi serta mencatatnya dalam buku kas harian oleh bendahara kemudian diakumulasikan untuk dibuat laporan keuangannya setiap bulan. Sedangkan di keempat lembaga amil zakat yang lainnya yakni LAZISMU Jember, YDSF Jember, Baitul Maal Hidayatullah (BMH) Cabang Jember, serta RIZKI siklus akuntansi dimulai dengan adanya penerimaan atau pengeluaran dana zakat yang dibuktikan dengan kwitansi pembayaran yang telah diklasifikasikan sesuai dengan jenis penerimaan dan jenis pengeluarannya, dan kemudian dicatat secara manual serta komputerisasi kemudian dibuat jurnal dan dicatat dalam buku besar, neraca saldo, baru kemudian dibuat laporan keuangan untuk masing-masing jenis dana.

Laporan keuangan yang dibuat Unit Pengumpul Zakat (UPZ) Kantor Departemen Agama Kabupaten Jember diterbitkan setiap bulan, dan tidak ada laporan keuangan komprehensif dalam satu tahun. Lembaga Amil Zakat LAZISMU Jember,
YDSF Jember, Baitul Maal Hidayatullah (BMH) Cabang Jember, serta RIZKI setiap bulannya membuat laporan keuangan yang berisikan informasi keuangan lembaga secara keseluruhan yang ditujukan untuk kalangan internal dan para donatur serta laporan keuangan komprehensif atas pertanggungjawaban terhadap dana yang dikelola selama periode satu tahun penuh yang dibuat setiap tahun yang ditujukan untuk yayasan. Bagi YDSF Jember pencatatan laporan keuangan tahunan berbeda dengan lembaga lain karena YDSF Jember hanya mencatat keuangan dalam jangka waktu 10 bulan dari Januari hingga Oktober dan disajikan pada bulan November. Sedangkan bagi lembaga amil zakat RIZKI tidak hanya membuat laporan keuangan setiap bulan dan tahunan, namun juga membuat laporan keuangan dalam periode 3 bulan.

Manajemen lembaga zakat secara berkala harus menerbitkan laporan keuangannya. Laporan ini menjadi sangat penting dalam rangka meningkatkan kepercayaan para calon muzakki. Keyakinan mereka terhadap lembaga zakat dapat dibangun melalui laporan keuangan yang benar. Laporan keuangan yang dibuat lembaga amil zakat haruslah sesuai dengan prinsip akuntansi yang berlaku umum, yaitu sesuai dengan prinsip akuntansi dalam hal pengakuan, pengukuran, pengungkapan dan penyajian. Namun dalam penelitian ini peneliti hanya berfokus pada penyajian laporan keuangan lembaga amil zakat.

\section{Penyajian Laporan Keuangan}

Penyajian menetapkan tentang cara-cara melaporkan elemen atau pos dalam seperangkat statemen keuangan agar elemen atau pos tersebut cukup informatif (Suwardjono, 2008:134). Dengan demikian lembaga zakat harus menyajikan informasi yang jelas, lengkap dan menggambarkan secara tepat mengenai kejadian ekonomi yang mempengaruhi posisi keuangan lembaga zakat. Penyajian laporan keuangan yang dibuat oleh Unit Pengumpul Zakat (UPZ) Kantor Departemen Agama Kabupaten Jember, LAZISMU Jember, YDSF Jember, BMH Cabang Jember serta RIZKI sebagai lembaga amil zakat adalah sebagai berikut:

\section{Laporan Posisi Keuangan (Neraca)}

Laporan posisi keuangan (neraca) belum dibuat oleh UPZ Kantor Departemen Agama Kabupaten Jember. Hal ini dikarenakan dana yang dihimpun oleh UPZ masih terbatas jumlahnya dan tidak adanya aktiva, piutang, maupun hutang sehingga pihak pengelola belum membuat laporan posisi keuangan (neraca). Begitu juga bagi LAZISMU Jember dan YDSF Jember. LAZISMU Jember masih belum membuat laporan posisi keuangan karena rusaknya sistem informasi ZIS (SIMAZIS) yang dimiliki sehingga pengurus lembaga hanya membuat laporan perubahan dana saja secara manual. Untuk YDSF Jember masih belum menyusun laporan posisi keuangan (neraca) karena terbatasnya dana serta terhitung masih mudanya umur lembaga. Selama ini YDSF Jember masih berada dibawah naungan YDSF Surabaya. Baru pada akhir tahun 2011 berdasarkan SK Kementerian Hukum dan HAM, YDSF Jember resmi berdiri sendiri dan mengelola keuangannya secara mandiri. Sedangkan untuk Baitul Maal Hidayatullah (BMH) Cabang Jember dan RIZKI sudah membuat laporan posisi keuangan berdasarkan PSAK 109 dimana terdapat pengelompokan akun menurut aktiva lancar dan aktiva tidak lancar (aktiva tetap), passiva, dan juga saldo dana.

e-Journal Ekonomi Bisnis dan Akuntansi, 2017, Volume IV (1) : 35-39 


\section{Laporan Perubahan Dana}

Untuk laporan perubahan dana UPZ Kantor Departemen Agama Kabupaten Jember telah membuatnya namun masih belum sesuai dengan PSAK 109 dimana masih belum adanya pengelompokan dana, format laporan keuangan yang masih sangat sederhana dikarenakan terbatasnya dana yang dihimpun, serta penggunaan kebijakan sendiri dalam penyusunan laporan keuangan sehingga terdapat perbedaan dalam penyajian format laporan perubahan dana. Untuk LAZISMU membuat Laporan Perubahan Dana secara sederhana dalam bentuk Rekapan Penerimaan dan Pengeluaran ZIS. Dalam rekapan tersebut telah dilakukan pemisahan antara dana zakat, dana infaq dan shadaqah. YDSF Jember juga membuat Laporan Perubahan Dana yang penyajiannya memisahkan antara dana zakat,infaq dan shadaqah. Sedangkan Laporan Perubahan Dana yang disajikan oleh Baitul Maal Hidayatullah (BMH) Cabang Jember dan RIZKI sudah sesuai dengan PSAK 109 yang didalamnya dibagi menjadi dana zakat, dana Infaq/Shadaqah, dana amil, serta dana non halal.

\section{Laporan Perubahan Aset Kelolaan}

Bagi kelima lembaga pengelola zakat di Kabupaten Jember yakni Unit Pengumpul Zakat (UPZ) Kantor Departemen Agama Kabupaten Jember, LAZISMU Jember, YDSF Jember, Baitul Maal Hidayatullah (BMH) Cabang Jember, serta RIZKI masih belum ada yang membuat dan menyajikan Laporan Perubahan Aset Kelolaan.

\section{Laporan Arus Kas}

Untuk Laporan arus kas Unit Pengumpul Zakat (UPZ) Kantor Departemen Agama Kabupaten Jember belum membuat laporan arus kas karena pada UPZ belum adanya transaksi berdasarkan tiga aktivitas sebagaimana yang tercantum dalam laporan arus kas berdasarkan PSAK 109. Begitu pun juga dengan LAZISMU Jember, YDSF Jember dan Baitul Maal Hidayatullah (BMH) Cabang Jember juga belum membuat laporan arus kas. Sedangkan RIZKI sudah membuat Laporan Arus Kas yang isinya sudah sesuai dengan PSAK 109.

\section{Catatan Atas Laporan Keuangan}

Untuk Catatan Atas Laporan Keuangan, dari kelima lembaga pengelola zakat di Kabupaten Jember yakni Unit pengumpul Zakat (UPZ) Kantor Departemen Agama Kabupaten Jember, LAZISMU Jember, YDSF Jember, Baitul Maal Hidayatullah (BMH) Cabang Jember dan RIZKI ini hanya lembaga amil zakat RIZKI yang membuat Catatan Atas Laporan Keuangan. Sedangkan untuk keempat lembaga yang lain masih belum membuat.

\section{Kesesuaian Penyajian Laporan Keuangan Lembaga Pengelola Zakat di Kabupaten Jember Berdasarkan PSAK 109}

Laporan keuangan yang disajikan oleh Lembaga Pengelola Zakat di Kabupaten Jember yakni Unit Pengumpul Zakat (UPZ) Kantor Kementerian Agama Kabupaten Jember, LAZISMU Jember, YDSF Jember, BMH Cabang Jember dan RIZKI dengan PSAK 109 dapat dilihat pada Tabel 1.

Lembaga Pengelola Zakat di Kabupaten Jember semua telah menyajikan laporan perubahan dana. Namun penyajian laporan perubahan dana yang sesuai berdasarkan PSAK 109 disini hanya pada lembaga zakat Baitul Maal Hidayatullah (BMH) Cabang Jember dan RIZKI. Untuk YDSF Jember,
LAZISMU Jember, serta UPZ Departemen Agama Kabupaten Jember dalam penyajian laporan perubahan dana masih belum sesuai dikarenakan hanya menyajikan penerimaan dana dan pengeluaran dana saja. Untuk laporan posisi keuangan (neraca) juga hanya RIZKI dan BMH Cabang Jember yang membuat serta telah sesuai PSAK 109. Untuk Laporan Perubahan Aset Kelolaan, kelima lembaga pengelola zakat di Kabupaten Jember masih belum ada yang membuat. Dan untuk laporan arus kas serta catatan atas laporan keuangan hanya RIZKI yang membuat serta telah sesuai dengan PSAK 109.

\section{Tabel 1. Perbandingan Laporan Keuangan Lembaga Pengelola Zakat di Kabupaten Jember}

\begin{tabular}{|l|l|l|l|l|l|}
\hline PSAK 109 & UPZ & LAZISMU & YDSF & \multicolumn{1}{|c|}{ BMH } & RIZKI \\
\hline $\begin{array}{l}\text { Laporan } \\
\text { Posisi } \\
\text { Keuangan } \\
\text { (Neraca) }\end{array}$ & Belum Ada & Belum Ada & Belum Ada & $\begin{array}{l}\text { Ada } \\
\text { (Sesuai) }\end{array}$ & $\begin{array}{l}\text { Ada } \\
\text { (Sesuai) }\end{array}$ \\
\hline $\begin{array}{l}\text { Laporan } \\
\text { Perubahan } \\
\text { Dana }\end{array}$ & $\begin{array}{l}\text { Ada } \\
\text { Belum } \\
\text { Sesuai) }\end{array}$ & $\begin{array}{l}\text { Ada } \\
\text { (Belum } \\
\text { Sesuai) }\end{array}$ & $\begin{array}{l}\text { Ada } \\
\text { (Belum } \\
\text { Sesuai) }\end{array}$ & $\begin{array}{l}\text { Ada } \\
\text { (Sesuai) }\end{array}$ & $\begin{array}{l}\text { Ada } \\
\text { (Sesuai) }\end{array}$ \\
\hline $\begin{array}{l}\text { Laporan } \\
\text { Perubahan } \\
\text { Aset } \\
\text { Kelolaan }\end{array}$ & Belum Ada & Belum Ada & Belum Ada & Belum Ada & Belum Ada \\
\hline $\begin{array}{l}\text { Laporan } \\
\text { Arus Kas }\end{array}$ & Belum Ada & Belum Ada & Belum Ada & Belum Ada & $\begin{array}{l}\text { Ada } \\
\text { (Sesuai) }\end{array}$ \\
\hline $\begin{array}{l}\text { Catatan Atas } \\
\text { Laporan } \\
\text { Keuangan }\end{array}$ & Belum Ada & Belum Ada & Belum Ada & Belum Ada & $\begin{array}{l}\text { Ada } \\
\text { (Sesuai) }\end{array}$ \\
\hline
\end{tabular}

\section{Hasil Analisis Penyajian Laporan Keuangan 1. RIZKI}

RIZKI telah membuat Laporan Posisi Keuangan (Neraca), Laporan Perubahan Dana, Laporan Arus Kas, dan Catatan Atas Laporan Keuangan. Laporan keuangan yang dibuat tersebut telah disajikan sesuai dengan PSAK 109. Laporan keuangan yang disajikan RIZKI ini dapat menjadi contoh bagi lembaga pengelola zakat di Kabupaten Jember yang lain. Namun untuk kelengkapan komponen laporan keuangan amil yang disebutkan dalam PSAK 109 masih kurang lengkap karena RIZKI masih belum membuat Laporan Perubahan Aset Kelolaan. Aset kelolaan merupakan aset yang dikelola dari dana infaq/shadaqah yang tidak terikat penyalurannya sehingga dapat dikelola untuk banyak golongan tidak terbatas pada delapan asnaf serta memberikan manfaat yang panjang. Oleh karena itu, jika RIZKI telah memiliki aset kelolaan maka harus membuat laporan perubahan aset kelolaan sesuai PSAK 109.

Laporan keuangan yang disajikan oleh RIZKI telah diaudit, namun hanya oleh auditor internal bukan auditor eksternal. Apabila laporan keuangan RIZKI telah diaudit oleh Kantor Akuntan Publik tentunya dapat memberikan nilai tambah bagi akuntabilitas lembaga yang nantinya juga akan meningkatkan kepercayaan masyarakat terhadap pengelolaan dana ziswaf yang dilakukan oleh RIZKI. 


\section{Baitul Maal Hidayatullah (BMH) Cabang Jember}

BMH Cabang Jember telah membuat Laporan Posisi Keuangan dan Laporan Perubahan Dana yang sesuai dengan PSAK 109. Sebagai kantor cabang, Laporan keuangan yang dibuat ini diserahkan kepada BMH Pusat untuk digabung dan nantinya di audit oleh Kantor Akuntan Publik. Namun, sebagai lembaga pengelola zakat seharusnya BMH juga membuat laporan perubahan aset kelolaan, laporan arus kas, dan catatan atas laporan keuangan berdasarkan PSAK 109. Hal ini untuk memudahkan masyarakat (donatur) dari BMH Cabang Jember dalam memahami pengelolaan dana zakat, infaq dan shadaqah yang dilakukan oleh Baitul Maal Hidayatullah (BMH) Cabang Jember.

\section{YDSF Jember}

Laporan Keuangan yang dibuat oleh YDSF Jember sampai saat ini masih membuat satu laporan keuangan saja yang dipublikasikan kepada masyarakat umum (donatur) yakni Laporan Penerimaan, Pengeluaran dan Saldo Kas/Bank. Dalam penyusunan laporan keuangan ini YDSF Jember masih menggunakan pecatatan sederhana sesuai dengan kebijakan sendiri dan belum berpedoman pada PSAK 109. Laporan ini dibuat setiap bulan dan direkap pada akhir bulan ke sepuluh untuk dipublikasikan pada akhir tahun.Laporan keuangan ini masih diaudit oleh auditor internal dari YDSF Jember sendiri. Hal ini dikarenakan YDSF Jember merupakan lembaga yang terhitung masih baru berdiri sendiri setelah awalnya berada dibawah naungan YDSF Surabaya. Namun sebagai lembaga pengelola zakat YDSF Jember harus menyajikan Laporan Keuangan yang sesuai dengan PSAK 109 dan diaudit oleh Kantor Akuntan Publik sebagai bentuk akuntabilitas agar semakin dipercaya oleh donatur dan dapat berkembang menjadi lembaga pengelola zakat lebih besar dan baik.

\section{LAZISMU Jember}

Laporan keuangan yang dibuat oleh LAZISMU Jember dapat dikatakan masih berupa satu laporan keuangan saja yaitu laporan pemasukan dan pendistribusian dana zakat, infak dan shadaqah yang hanya menyajikan jumlah dana yang dikumpulkan serta pendistribusian dana yang sesuai dengan karakteristiknya. Laporan keuangan ini juga masih di audit oleh auditor internal saja.

Dengan penyajian laporan keuangan yang seperti ini seharusnya LAZISMU Jember menerapkan PSAK 109 sebagai pedoman dalam menyusun laporan keuangan agar dapat lebih mudah dipahami oleh masyarakat umum (donatur) dan dapat dibandingkan kinerjanya dengan lembaga zakat yang lainnya. Selain itu juga laporan keuangan yang dibuat nanti dapat diaudit oleh Kantor Akuntan Publik sebagai pertanggungjawaban serta agar lebih transparan sehingga lebih dipercaya oleh para donatur.

\section{Unit Pengumpul Zakat (UPZ) Kantor Departemen Agama Kabupaten Jember}

Laporan keuangan yang dibuat oleh UPZ Kantor Departemen Agama Kabupaten Jember hanya 1 laporan keuangan yakni Laporan Sumber dan Penggunaan Dana serta masih belum sesuai dengan PSAK 109. UPZ hanya membuat 1 laporan keuangan saja dikarenakan terbatasnya jumlah dana yang dikumpulkan dari lingkungan internal Kantor Departemen Agama Kabupaten Jember meliputi pegawai dan 18 Satker yang berada dibawah naungannya. Namun sebagai pengelola zakat, UPZ sebaiknya membuat laporan keuangan yang lengkap sesuai dengan PSAK 109 yakni Laporan Posisi Keuangan (Neraca), Laporan Perubahan Dana, Laporan Perubahan Aset Kelolaan, Laporan Arus Kas, dan Catatan Atas Laporan Keuangan.

\section{Simpulan dan Keterbatasan}

\section{Simpulan}

Berdasarkan kajian pembahasan menunjukkan bahwa proses akuntansi Unit Pengumpul Zakat (UPZ) Kantor Departemen Agama Kabupaten Jember dimulai dari adanya penerimaan atau pengeluaran yang dibuktikan dengan bukti transaksi yaitu kwitansi serta mencatatnya dalam buku kas harian oleh bendahara kemudian diakumulasikan untuk dibuat laporan keuangannya setiap bulan. Sedangkan di keempat lembaga amil zakat yang lainnya yakni RIZKI, Baitul Maal Hidayatullah (BMH) Cabang Jember, LAZISMU Jember serta YDSF Jember siklus akuntansi dimulai dengan adanya penerimaan atau pengeluaran dana zakat yang dibuktikan dengan kwitansi pembayaran yang telah diklasifikasikan sesuai dengan jenis penerimaan dan jenis pengeluarannya, dan kemudian dicatat secara manual serta komputerisasi kemudian dibuat jurnal dan dicatat dalam buku besar, neraca saldo, baru kemudian dibuat laporan keuangan untuk masingmasing jenis dana.

Selanjutnya untuk penyajian laporan keuangan lembaga pengelola zakat di Kabupaten Jember sebagaimana berikut ini a. RIZKI menyajikan empat komponen laporan keuangan yakni Laporan Posisi Keuangan, Laporan Perubahan Dana, Laporan Arus Kas dan Catatan Atas Laporan Keuangan. Namun, dalam penyusunan empat laporan keuangan tersebut sudah berpedoman pada PSAK 109.

b. BMH Cabang Jember menyajikan dua komponen laporan keuangan yakni Laporan Posisi Keuangan dan Laporan Perubahan Dana. Namun, dalam penyusunan dua laporan keuangan tersebut sudah berpedoman pada PSAK 109.

c. LAZISMU Jember menyajikan laporan keuangan perubahan dana saja secara sederhana dan belum berpedoman pada PSAK 109.

d. YDSF Jember menyajikan laporan keuangan perubahan dana saja secara sederhana dan belum berpedoman pada PSAK109.

e. UPZ Departemen Agama Kabupaten Jember menyajikan laporan keuangan perubahan dana saja secara sederhana dan belum berpedoman pada PSAK 109.

\section{Referensi}

Eriyanto. 2009. Analisis Wacana: Pengantar Analisis Teks Media. Yogyakarta: Lkis.

Exposure Draft PSAK 109. Akuntansi Zakat dan Infak/Sedekah.

Fathonah. 2013. Analisis Penerapan Akuntansi Zakat Pada Organisasi Pengelola Zakat (Studi Kasus LAZISMU Kabupaten Klaten dan BAZDA Kabupaten Klaten)

Indriantoro, Nur., dan Supomo, B. 2009. Metodologi Penelitian Bisnis untuk Akuntansi dan Manajemen. Yogyakarta: BPFE Yogyakarta.

Miles, Matthew B., A. Michael Huberman. 1992. Analisis Data Kualitatif: Buku Sumber Tentang Metode-metode Baru. Jakarta: Universitas Indonesia (UI-Press).

Muhammad, Rifqi. 2008. Akuntansi Keuangan Syariah, Konsep dan Implementasi PSAK Syariah, Ed. 1. Yogyakarta: P3EI Press.

Sugiyono. 2014. Memahami Penelitian Kualitatif. Bandung: Alfabeta.

Suwardjono. 2008. Teori Akuntansi. Perekayasaan Pelaporan Keuangan. Yogyakarta: BPFE

Undang-Undang Republik Indonesia Nomor 23 Tahun 2011. Tentang Pengelolaan Zakat. 